\title{
都市韓屋の増改築事例における出入関係からみたチェとマダンのつながり方 \\ THE RELATIONSHIP BETWEEN CHAE AND MADANG CORRESPONDING TO THE EXTENSION AND ALTERATION OF URBAN HANOK
}

\author{
金 海 梨*, 高田光雄**, 金 泰 永*** \\ Haeri KIM, Mitsuo TAKADA and Taiyoung KIM
}

\begin{abstract}
This study aimed to identify the characteristics in relationship between Chae and Madang corresponding to the extension and alteration of L-shape urban Hanok, which is a standard urban Hanok shape in central Korea. The results of the study showed that studied five urban Hanok corresponded to the needs of residents through extensions and alterations, although these wooden buildings were built more than 50 years ago. However, the current life pattern did not fully appreciate the traditional space organization of Hanok, which organically connected Chae and Madang, and the merits of life culture within the connection.
\end{abstract}

Keywords : Korea, Urban Hanok, Chad(Residential building), Madang(Yard), Alteration

韓国，都市韓屋，チェ(住棟)，マダン(庭)，改築

\section{1.はじめに}

\section{1 研究の背景と目的}

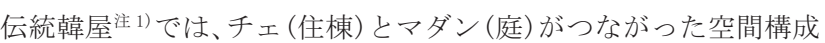
に基づき、季節ごとの建具の開閉や空間の使い分けにより、住まい 手が自ら屋内外の関係を調整することで、人と自然が調和した生活 文化を育んできた。しかし、近年の新韓屋開発の動向注2)をみる、 伝統的な韓屋の外皮を取り入れつつ住宅内部の気密性や断熱性を高 めることを最優先にしており、必ずしもチェとマダンのつながりが 豊かな住み方の良さが十分に配慮された計画であるとは言えない。

このような問題に着目し、既報注3)では、伝統韓屋から都市韓屋へ の移行期の韓屋を取り上げ、チェとマダンがつながった空間構成は 時代を超えて朝鮮戦争直後という特殊な社会状況の下でも継承され ていることを明らかにした。また、マダンは単に物理的に残されて いるだけではなく、四季を通じて様々な使われ方がされており、住 まい手の生活を多面的にサポートしていることも明らかになった。 本稿では引き続きチェとマダンのつながりに着目し、増改築が繰り 返され、現在も寸み続けられている「都市韓屋注 4 )」を取り上げ、住 まい手の住要求への対応を探る。

以上を踏まえ本稿では、建物の「物理的な状態」と「使われ方」 という観点から出入関係の変化について分析し、都市韓屋における チェとマダンのつながり方の特徵を明らかにすることを目的とする。

\section{2 既往研究と本研究の位置づけ}

都市韓屋における増改築の実態や内部空間であるチェの利用実態 について検討した研究は少なくない注5)。また、筆者らによるものも 含めて、外部空間であるマダンの利用実態を取り扱った一連の研究
がある注6)。一方、既報でも指摘したように、チェとマダンがつなが った空間構成の特徵に着目した一連の研究があるが、それらは伝統 韓屋を対象としたものである。本稿は、時代と社会の変化に伴う住 まい手の住要求の変化に対応してきた住宅形式である都市韓屋に着 目し、チェとマダンのつながり方の特徴を明らかにしている点に独 自性がある。

\section{3 研究の対象と方法}

都市韓屋の基本的な形注 7) とされる $\mathrm{L}$ 字型韓屋の事例を取り上げ る。研究対象は、韓国の中部地方都市である清州市の旧市街地に残 存している「中部地方の $\mathrm{L}$ 字型韓屋 (以下、 $\mathrm{L}$ 字型韓屋) ${ }^{\text {注 }}$ )」事例と する(図 1)。本調查は全 2 回行った。1 次調查では、実測及び住まい 手に対するインタビュー調查を行い、建物の増改築実態及び屋内空 間の使われ方を把握した。2 次調査では、住まい手に対するインタ ビュー調查及び現状確認を行い、マダンを中心に屋外空間の使われ 方を把握した注 9)。第 2 章では、既往文献に基づいて中部地方の L 字型都市韓屋の概要について説明する。第 3 章では、対象事例にお ける増改築の現状を明らかにする。第 4 章では、チェとマダンの使 われ方の変化を明らかにする。それらを踏まえ、第 5 章では、出入 関係からみたチェとマダンのつながり方を明らかにする。

\section{2. 研究対象の概要}

\section{1 都市韓屋及び $\mathrm{L}$ 字型都市韓屋}

都市韓屋注 10) は、1930～1960 年代にかけて大都市を中心に建てら れた都市型の住宅で、伝統韓屋では使われない近代的建築材料が積 極的に導入されている注 11 。居住者階層は中産層の都市住民で、都

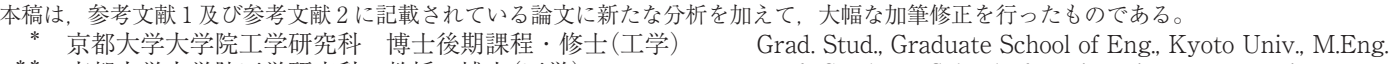

** 京都大学大学院工学研究科 教授・博士(工学) $\quad$ Prof., Graduate School of Engineering, Kyoto Univ., Dr.Eng.

***＼cjkstart韓国清州大学大学院工学研究科 教授·博士(工学) Prof., Dept. of Architecture, Cheongju University, Dr.Eng.
} 


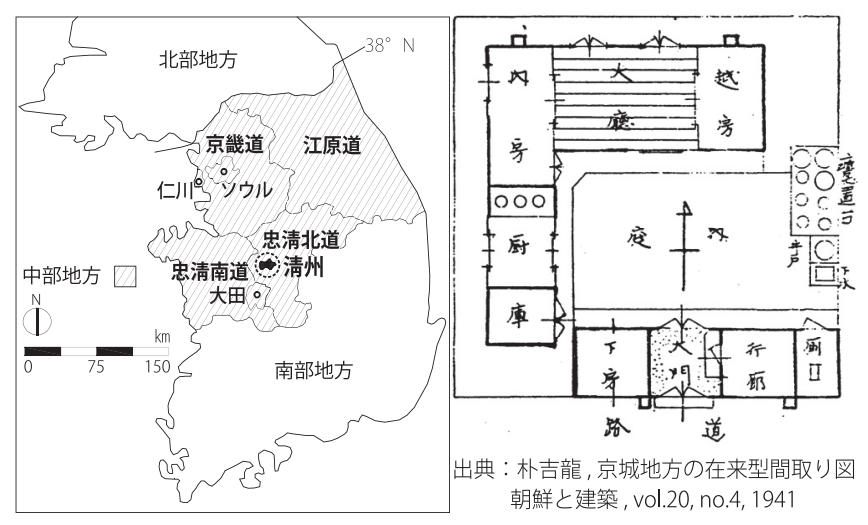

図 1 調査対象地の位置 (左) と中部地方の $L$ 字型都市韓屋の間取り (右)

心部の狭い敷地を有効に活用して都市住民の住要求を受容する韓屋 群として建設された。母屋の形は L 字やコ字のような土地節約型の 曲家が多い ${ }^{13)}$ 。中部地方の $\mathrm{L}$ 字型都市韓屋の典型的な間取り注 ${ }^{12)}$ 図1(右)に示す。この住宅では、内房(アンバン; 夫婦寝室、以下、 内房)を中心に大庁 (デチョン;板張りの居間、以下、大庁) と釜屋 (プ オク；土間の台所、以下、釜屋)がL字に結合している。大庁を間に し、内房の反対側には子女部屋として使われる越房(コンノンバン； 以下、越房)が配置される。住宅の規模によって房 (バン; 部屋)や退 抹楼 (トェッマル; 縁側、以下、縁側)が追加されることもある注 13 )。 また、上の房注 ${ }^{14)}$ の方で結合される屋根の構造が特徵である。本研 究では、増改築の実態やそれに対応した住み方を把握し、各事例に おけるチェとマダンのつながり方を明らかにするために、上述した 2 つの特徴が保持されている事例のみを調查対象としている。

\section{2 対象事例の概要}

対象事例の建物概要と居住者属性を表 1 に示す。 5 軒とも 1935 年 から 1959 年の間に建てられ、築 50 年以上経過している。チェの面 積は、 $48.2 \mathrm{~m}^{2}$ から $75.3 \mathrm{~m}^{2}$ までで、全ての事例に一つ又は二つの別 棟がある。事例 01 ・ 02 では 3 世代、事例 03 ・ 05 では 2 世代が同居 しており、事例 04 では世帯主夫婦が住んでいる。居住年数は 5 軒と も 30 年以上である。

\section{3. 増改築の現状}

増改築の現状を図 2 に、現状に至る経緯を表 2 に示寸。また、主 な増改築の項目とその理由を表 3 に示す。

\section{1 建物後面の増築}

\section{(1) 個室規模を拡張するための増築}

事例 01 (内房、孫娘房、大庁) - 02 (内房、孫娘房、孫房、息子夫 婦房) ・ 03 (内房、釜屋)で行われた。韓屋の基本モジュールは 2.4 $2.7 \mathrm{~m}$ であるが、床座中心から椅子座中心の生活への移行に伴い、個
室の面積を占める家具の数が増えたり家具のサイズが大きくなった りし、空間が足りなくなった。それに対応して建物後面から敷地境 界線の間にある屋外空間を使って増築が行われている。

01 事例では、孫たちが小学校に入学する前後に、成長する孫と孫 娘の個室を設けるために間仕切壁を新設し、狭い空間を拡張するた めに孫娘房の後面と孫房の側面を増築した (表 2-事例 01-増築1)、 (3))。1970 年代初に 4 人家族で入居した 02 事例では、個室を拡張す るための増築が 2 回に渡って行われた。入居当時から家の一部を借 家として使うことを想定していたので家族構成員のための個室が足 りず、内房に間仕切壁を新設した。その上で、空間を拡張するため に内房、孫娘房の後面を増築したものである。1980 年代後半に息子 さんの結婚と同時に現在の孫房と息子夫婦房の後面を増築した (表 2-事例 02-増築(1)、(3)。03 事例では、入居時に内房と釜屋を拡張す るために後面を増築している(表 2-事例 03-増築(4))。

\section{(2) 付属空間を新設するための増築}

該当する全ての事例においてボイラー室又は現代の住設備が備わ った水回りが新設されており、付属空間の新設は燃料の発達による 新しい炊事及び暖房設備の導入と影響していると考えられる。

事例 01 では、大庁の後面を増築し、本棚を入れて家族共用の書庫 を新設している。また、息子夫婦房の後面を増築して多用途室を新 設し、ボイラーを置くとともに専用の泠蔵庫と洗濯機を設置し、息 子夫婦のプライバシーを重視している（表 2-事例 01-増築(2)、(4)）。 事例 02 では、孫房と孫娘房の後面及び旧借家 (現物置)の後面を増築 し付属空間を新設している。現在はボイラー室であるが、借家世帯 が住んだ時期は単独炊事が可能な簡易釜屋でもあった（表 2-事例 02-増築(2)。事例 03 では、内房の後面を増築して倉庫を、息子寝室 の後面を増築して洗面及び洗濯室を新設している。また、息子寝室 の後面には外部からアクセス可能な和式便所を新設した(現在は倉 庫に改築されている) (表 2-事例 03-増築(2)、(3))。05 事例では、1997 年に新しい炊事及び暖房設備を導入すると同時に住宅全体的に増改 築を行い、トイレと大庁及び内房の後面を増築してボイラーやその 他のものを収納するための倉庫を新設している(表 2-事例 05-増築)。

\section{2 間仕切り及び室位置の変更に係る改築}

\section{(1) 家族構成員の減少に伴う個室の統合}

事例 03 では、入居当時の 1977 年、空間を広く使うために内房に あった間仕切壁を撤去している(表2-事例 03-改築(2)。事例 04 では、 1978 年入居当時から内房を $2 つ の$ 個室に区切っていた間仕切壁をそ のまま維持し、釜屋に接している方は世帯主夫婦が、押入がある方 は二人の息子が使っていた。子供の分家後も 2 つの個室に分かれて いる内房の状態はそのままだったが、義母の死亡後、内房の間仕切 壁を撤去した。また、内房をさらに広く使うために小部屋の建具を

表 1 対象事例の基本属性

\begin{tabular}{|c|c|c|c|c|c|c|c|c|}
\hline \multirow{2}{*}{$\begin{array}{l}\text { 事例 } \\
\text { 番号 }\end{array}$} & \multicolumn{5}{|c|}{ 建物概要 } & \multicolumn{2}{|l|}{ 居住者属性 } & \multirow{2}{*}{ インタビュ一対象 } \\
\hline & 建築年 & 敷地面積 & 延床面積 & 建物構成 & 入居年 & 居住者の構成(年齢) & 人数 & \\
\hline 01 & 1935 & $207.3 \mathrm{~m}^{2}$ & $75.3 \mathrm{~m}^{2}$ & 主+別 & 1970 & I CO:M(77) • F(70 代)+ IICO:長 M(40 代) • F(40 代)+IIIF(17)・M(15) & 6 & I COのM \\
\hline 02 & 1936 & $199.9 \mathrm{~m}^{2}$ & $73.0 \mathrm{~m}^{2}$ & 主+別 & 1970 年代初 & I CO:M(77) $\cdot F(72)+$ II CO:長 $M(46) \cdot F(42)+I I F(13) \cdot F(11) \cdot M(9)+I \mid I F(22) *$ & 8 & $\mathrm{ICO}$ \\
\hline 03 & 1959 & $149.7 \mathrm{~m}^{2}$ & $48.2 \mathrm{~m}^{2}$ & 主+別 & 1977 & $\mid M(76)+\| M(28)$ & 2 & I M \\
\hline 04 & 1935 & $211.9 \mathrm{~m}^{2}$ & $58.5 \mathrm{~m}^{2}$ & 主+別+別 & 1978 & I CO:M(78) $\cdot F(77)$ & 2 & ICOのF \\
\hline 05 & 1952 & $246.5 \mathrm{~m}^{2}$ & $65.0 \mathrm{~m}^{2}$ & 主+別+別 & 1981 & I CO:M(56) • F(54)+ II 次 $M(27)$ & 3 & ICOのF \\
\hline $\begin{array}{l}\text { ※表 } \\
\text { 主: } \\
*:\end{array}$ & 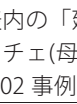 & $\begin{array}{l}\text { 聿物概要」 } \\
\text { 屋) 別: } \\
\text { では、世帯 }\end{array}$ & $\begin{array}{l}\text { 建築物臺 } \\
\text { 別棟(離れ) }\end{array}$ & $\begin{array}{l}\text { 帳の記録及 } \\
\text { | || ||| : } \\
\text { 家族、そし }\end{array}$ & $\begin{array}{l}\text { び現場確認に基 } \\
\text { 世代 陰影 } \\
\text { て長女の娘( }\end{array}$ & 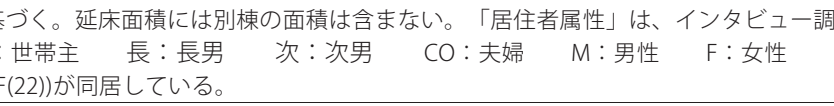 & $\begin{array}{l}\text { 周査に基 } \\
\text { (数字) }\end{array}$ & $\begin{array}{l}l ゙<。 \\
\text { : 韓国歳 }\end{array}$ \\
\hline
\end{tabular}


撤去し、日常的に使う寝具や家具を置いている(表 2-事例 04-改築(3)、 撤去(1)）。事例 05 では、1997 年、都市計画による敷地境界線の変更 により、建物や井戸を撤去せざるを得なかった。それをきっかけで、 必要に応じて住宅全体的に増改築を行うことにし、内房の間仕切壁 を撤去している(表 2-事例 05-改築(2) 。

\section{(2) 家族構成員の増加に伴う個室の分割}

01 事例では、成長する孫娘と棌のプライバシーを配慮し、建具で 区切っていた孫娘房と孫房の間に間仕切壁を取り付けている(表 2事例 01-改築(1)、撤去(2)。02 事例でも同じ改築が行われている。3 世代 8 人が同居している事例 02 では、既存の内房にあった建具を撤 去し間仕切壁を取り付け、孫娘房を確保している。また、入居時に は一室となっていた居室の右側の部屋に間仕切壁を取り付け、孫房 と息子夫婦房を確保している (表 2-事例 02-改築(1)、撤去)。以上か ら、対象事例では家族構成員の増減に対応し個室を分割又は統合寸 る改築が行われていることが分かる。

\section{(3) その他}

釜屋の位置を変更するための改築が行われた場合もある。事例 02 では、入居当時、借家を入れるために釜屋を居間の方に移っている (表 2-事例 02-改築(2)、表 3-改築-間取りの変更)。一方、事例 01 ・ $03 \cdot 04 \cdot 05$ では、釜屋の位置が入居当時から現在まで維持されてお り (図 2)、L 字型韓屋の間取り (図 1 の右) における釜屋の位置と同じ である。対象事例は築 50 年以上経過している古い住宅ではあるもの の、内房を中心に釜屋と大庁が接続している間取りは現代の生活に も対応できていると考えられる。

\section{3 建具の変更及び縁側の内部化に係る改築 (1) 屋内空間の断熱性・気密性を高めるための建具の変更}

事例 01〜05 全てにおいて、断熱性と気密性の改善を図るために外 気に面する建具が木製枠からアルミサッシ、または PVC サッシへと 変更されている(図 2、表 2、表 3)。さらに、事例 01 (息子夫婦房、 表 2-事例 01-改築(4) ・ 02 (旧借家と息子夫婦房) ・ 03 (息子房、表 2事例 03-改築(3)、(5))では、マダンに面する空を二重空に変更してお り、事例 05 では、外気に面する全ての空が二重空となっている(表 2-事例 03-改築(4))。出入口の建具を撤去し、空に変更している事例 もある。事例 01 では、息子夫婦のプライバシーやサイズの大きい既 成家具の使用を配慮し、マダンとの出入口をアルミサッシの窓に変 更している(表 2-事例 01-改築(3)）。事例 02 では、内房及び孫娘房、 孫房後面の出入口及び孫房前面の出入口を撤去し、空に変更してい る。同じようなことが息子夫婦房の前面にも行われている(表 2-事 例 02-改築(3))。息子夫婦房では倉庫を新設するために、後面の出入 口を撤去し、壁に変更している。また、居室後面を増築して釜屋と トイレを新設するために出入口を撤去し、空に変更している(表 2事例 02-新築・新設(2)、改築(4))。事例 04 では、内房後面及び越房 前面の出入口を空に変更している(表 2-事例 04-改築(3)。

上述した改築時期は燃料や暖房設備が変わった時期と重なってお り、建具の変更は、燃料の発達に伴う冷暖房設備の改善と影響して いることが分かる。また、夏の暑さより冬の寒さに対応することを 重視する改修が行われてきたことが分かる。このような傾向は、次 に述べる縁側の内部化とも関連していると考えられる。

\section{(2) 収蔵空間を確保するための縁側の内部化}

マダンと接しており出入も可能だった縁側が内部化されている。
その過程で、入居当時にあったマダンと縁側との出入が閉鎖的に変 わっている。事例 03 (息子寝室の側面、表 2-事例 03-改築(4))では、 出入口を空に、事例 04 (越房の側面、表 2-事例 04-改築(1))では、出 入口を取り壊して開口部が全くない壁に改築されている。その結果、 内部空間で必要な機能の充足は可能となったものの、半屋外空間と しての縁側の特徴は失われている。

\section{4 住設備空間の改善のための改築および新築}

事例 01〜05 全てにおいて、暖房設備と炊事設備が改善されている。 燃料の発達により、釜屋の焚口で炊事と暖房を兼初ていた在来の方 式からの切り替えが行われた。在来の釜屋は、炊事と暖房を兼ねる 焚口を使っていたため床のレベルが内部の部屋より低く、マダンと 同じレベルの土間であった。改築の時期は事例ごとに異なるが、5 軒とも炊事と暖房を分離し、現代の設備を導入している(表 2)。釜 屋の改築に関連した物理的変化として、事例 $03 ・ 05$ では、内房から 出入可能で釜屋の上部にあったタラク (屋根裏部屋)が撤去されてい る。一方、事例 $01 ・ 04$ では、タラクが保持できる階高を確保しつつ 現代のキッチン設備が導入されている(図 2)。

便所及び浴室などの衛生設備空間を拡充するための改築や新築・ 建て替えも行われた。都市韓屋建設当時の便所は汲み取り式で、別 棟として屋外の一角に建てられることが一般的だった注 ${ }^{15)}$ 。しかし、 対象事例では、衛生設備を改善寸るために別棟を建て替え、水洗式 トイレが備えられている。事例 01〜03 では、入居当時にあった汲み 取り式便所を撤去し、洋式便器を使うトイレに、事例 04 では入居当 時あった汲み取り式便所を撤去し、和式便器を使うトイレに建て替 えている。事例 05 では、水洗式の屋外トイレが撤去された直後に家 全体の増改築を行い、屋内にトイレを新設している。また、事例 01 ・ 04 では建て替えた水洗式トイレの横に浴室を、事例 05 では屋内卜 イレを新設する際に屋外に洗濯室と浴室を兼社た水回り空間を新設 している(図 2、表 3)。

\section{4. チェとマダンの使われ方の変化}

\section{1 チェの使われ方の変化}

\section{(1) 季節に応じた住み方の変質}

全ての事例において増改築後のチェの使われ方が閉鎖的なものに 変わっている。断熱性や気密性を高めるために出入口を空に、個室 規模の拡張や収蔵空間確保のために既存の縁側や部屋にあった開口 部を壁に変えている。そのため、入居当時よりチェの各室とマダン との出入口が減少し、屋内外空間の物理的接続そのものが少なくな っている。さらに、夏期を快適に過ごすために板張り空間に仕上げ られた大庁は、冬期の寒さに対応して他の個室と同じく床暖房をつ ける空間に改築されている。その結果、季節に応じて住まい手自ら が建具の開閉によって住宅の温熱環境を調整する住み方がなくなっ てきた。オンドル部屋と板張り空間であるマルが併置され、夏期と 冬期の両方に対応した住み方から、冬の寒さを防ぐことを重視した 住み方へと変化してきたものである。

\section{(2)半屋外空間としての縁側機能の消失}

チェとマダンをつなぐ半屋外空間であった縁側は、増改築によっ て内部化され、屋内空間の一部として使われている。事例 $01 \cdot 05$ では、マダンに面して建物前面に縁側がついているが、主に通路と して使われている。事例 03・04 では建物側面に縁側がついていたが、 
表 2 現在に至るまでの経緯（増改築の内容と居住者属性の変化を中心に）

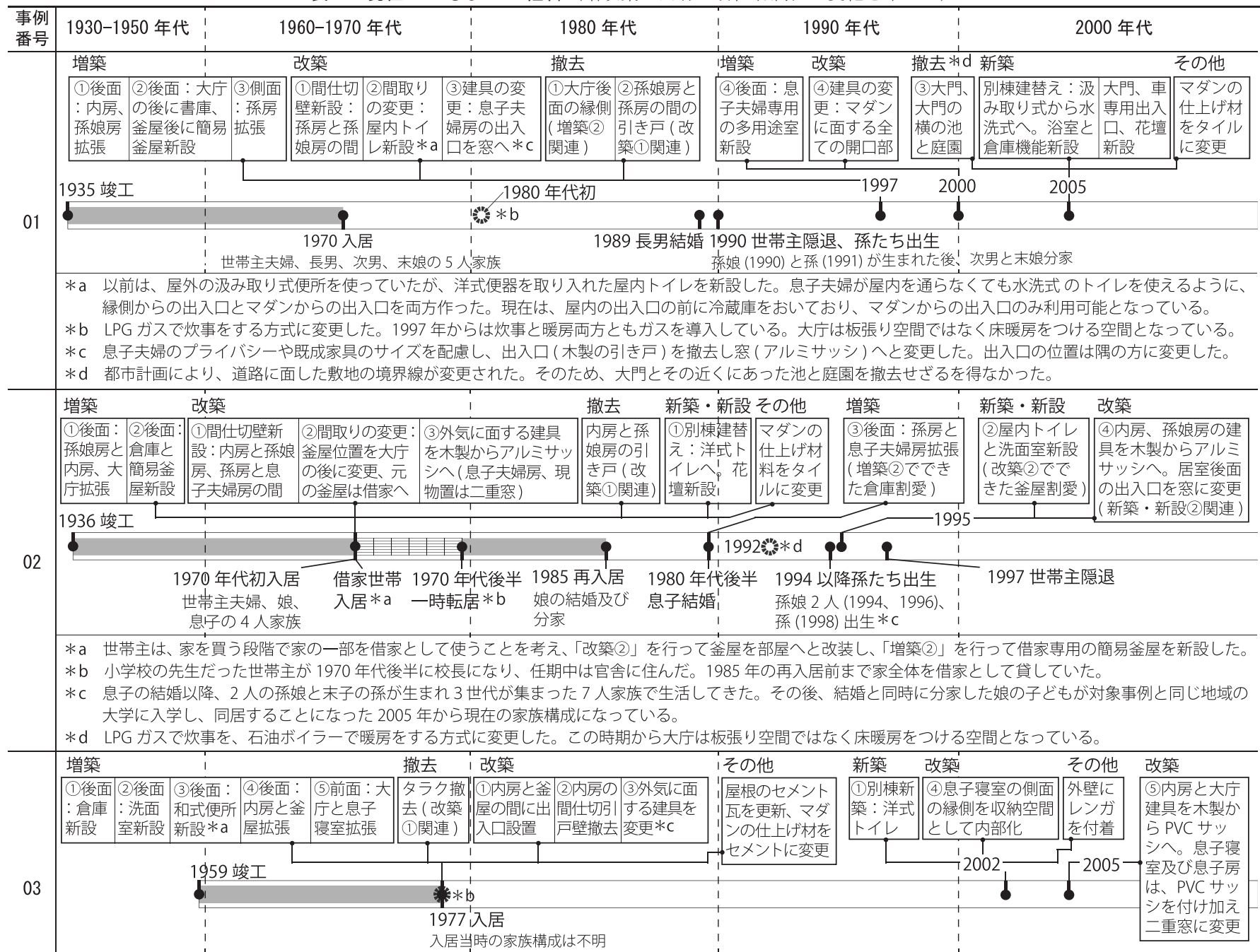

*a 洗面室から出入可能な便所だったが、後日改造され、現在は倉庫となっている。

*b 炊事と暖房を兼ねていた土間の釜屋を内部化したガスキッチンに改造する過程でタラクを撤去し、内房から釜屋への出入口を作った。

LPG ガスで炊事を、石油ボイラーで暖房をする方式に変更した。この時期から大庁は板張り空間ではなく床暖房をつける空間となっている。

*c 外気に面する建具を木製サッシからアルミサッシに変更している。その他、屋内空間の建具は木製の引き戸や開き戸をそのまま使っている

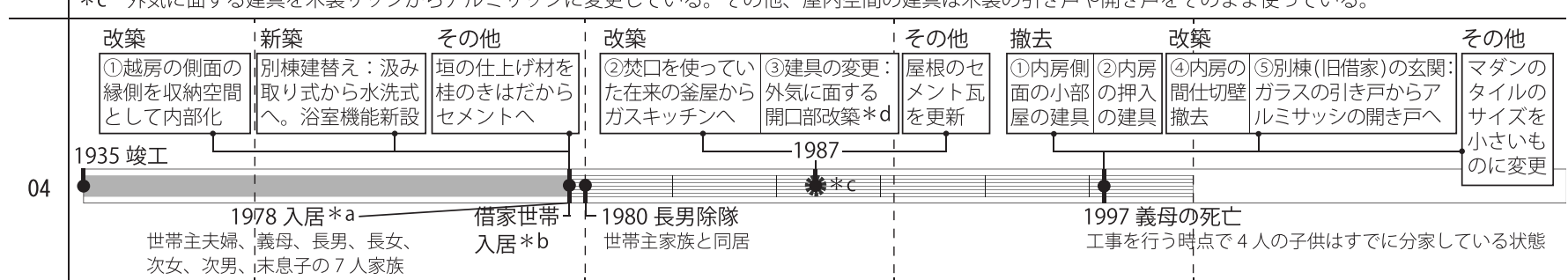
次女、次男、枺息子の 7 人家族

*a 入居当時、長男は二十歳で軍隊に入っていた。そのため、除隊してから同居した。

*b 借家世帯は途中に入れ替わりがあり、大体 1990 年代まで住んでいた。入れ替わりの回数や個々の借家世帯の入居期間については確認が取れていない。

*c LPG ガスで炊事を、石油ボイラーで暖房をする方式に変更した。この時期から大庁は板張り空間ではなく床暖房をつける空間となっている。

*d 外気に面する建具及び内房と大庁の間の建具を障子の開き戸からガラスの木製サッシの引き戸に変更し、内房後面及び越房前面の出入口は空に変更している。

撤去 $\quad$ 改築

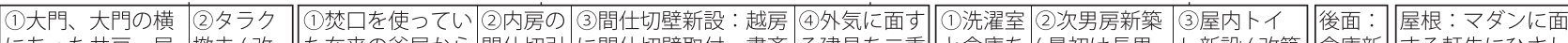
にあった井戸、屋 撤去 (改 た在来の釜屋から間仕切引に間仕切壁取付、書斎 る建具を二重 と倉庫を(最初は長男 し新設 (改築 倉庫新 卞る軒先にひさし

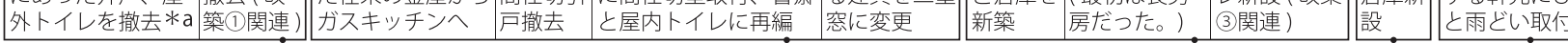

05

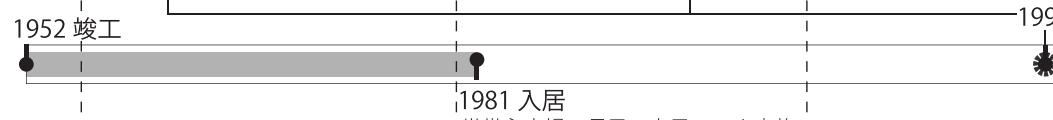

1 1981 世帯主夫婦、長男、次男の 4 人家族 !

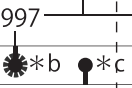

1999'長男分家

*a 都市計画により、道路に面した敷地の境界線が変更された。そのため、大門とその近くにあった別棟や井戸を撤去せざるを得なかった。

*b LPG ガスで炊事を、石油ボイラーで暖房をする方式に変更した。この時期から大庁は板張り空間ではなく床暖房をつける空間となっている。

*C 長男は 1998 年から ROTC 将校として入隊し、除隊後は就職先の近くに引つ越した。
〈凡例〉

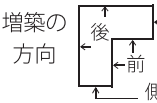
b建物に関連する経緯
曰他の住まい手が住んだ期間
借家世帯と同居していた期間
P 住まい手に関連する経緯
口現在の住まい手が住んでいる期間
燃料の変更と釜屋の改造
(※ 間仕切りの変更に係る工事の場合、間仕切壁の新設・撤去両方とも「改築」欄に表記する。) 


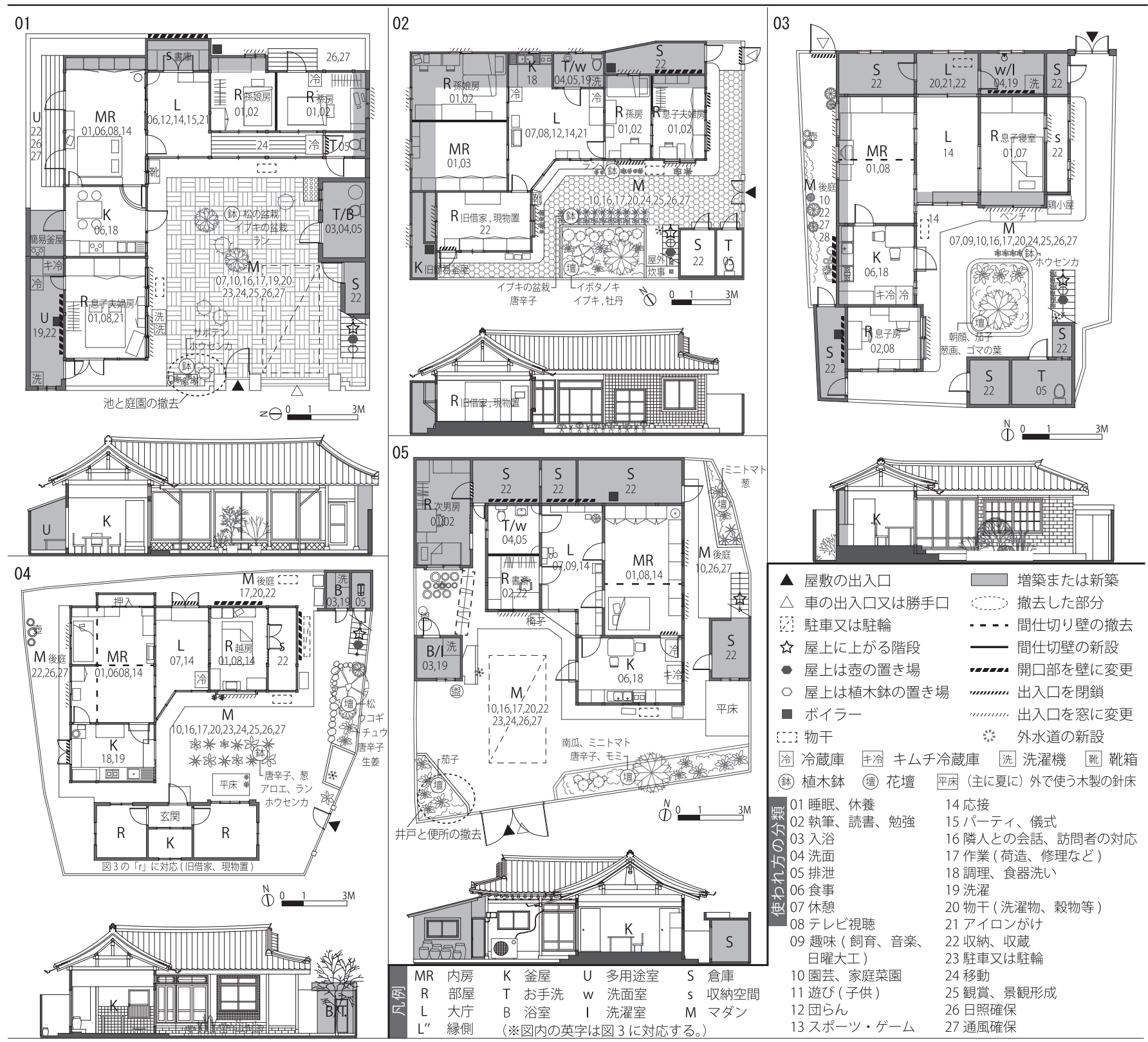

図 2 増改築後の現状及びチェとマダンの使われ方

現在は個室に付属した収蔵空間となっている。対象事例では、縁側 は夏期には少し暑く冬期には少し寒い、季節感が感じられる空間で あったが、現在ではそのような緩衝空間の性質は失われている。

事例 03(図 2、息子寝室の側面) ・ 04 (図 2、越房の側面)では、縁 側が個室に属した収納空間として使われている。事例 01 (孫娘房と 孫房の前面の縁側) では、マダンとの出入は変わりなくできるものの、 縁側に座って雨の風景をみたり子供が遊んだりするなどの生活行為 は行われておらず、通路となっている。これは、孫娘と孫が成長し 中高生になっていること(表 1) とも影響していると考えられる。

\section{2 マダンの使われ方の変化}

都市韓屋においてマダンは本来、ほとんどが空地の状態で保持さ れ、家庭の行事や家事を始めとして住まい手の様々な生活行為が行 われる多目的な屋外空間として使われた。また、そのような使われ 方は、伝統韓屋におけるアンマダン (内庭) の特徵が時代を超えて引 き継がれたものである注 ${ }^{16)}$ 。それに対して、対象事例におけるマダ
ンの使われ方はどのように異なっているのかについて検討する。

\section{(1) 住宅へのアクセス及び環境調整空間}

マダンの使われ方を図 2 に示す。マダンは、増改築が行われた後 も入居当時と同様に道と屋敷、屋外と屋内をつなぐアクセス経路と して使われている。また、全ての事例において、マダンは風通しや 採光が自然的に行える環境調整空間注 17) として機能している。特に、 チェの増改築や別棟の建替え及び新築が行われつつも、敷地中央を 空けておくことにより環境調整機能を持たせるようになっている。

\section{(2) 家事及び作業空間}

都市韓屋では、マダンの一角に奨壱台があり（図1の右）、マダン は釜屋の延長線上で家事を行う空間としても使われていた。奨营台 は、キムチや奨油、味噌やコチュジャンなどを長期間保存する壼の 置き場として使われたものである。対象事例では、増改築を前後に して螜の使われ方に変化が見られる。事例 01〜04では建て替えた別 棟の屋上が壼の置き場として使われている。事例 05 では、別棟の屋 
表 3 対象事例における増築・改築 · 新築内容と理由

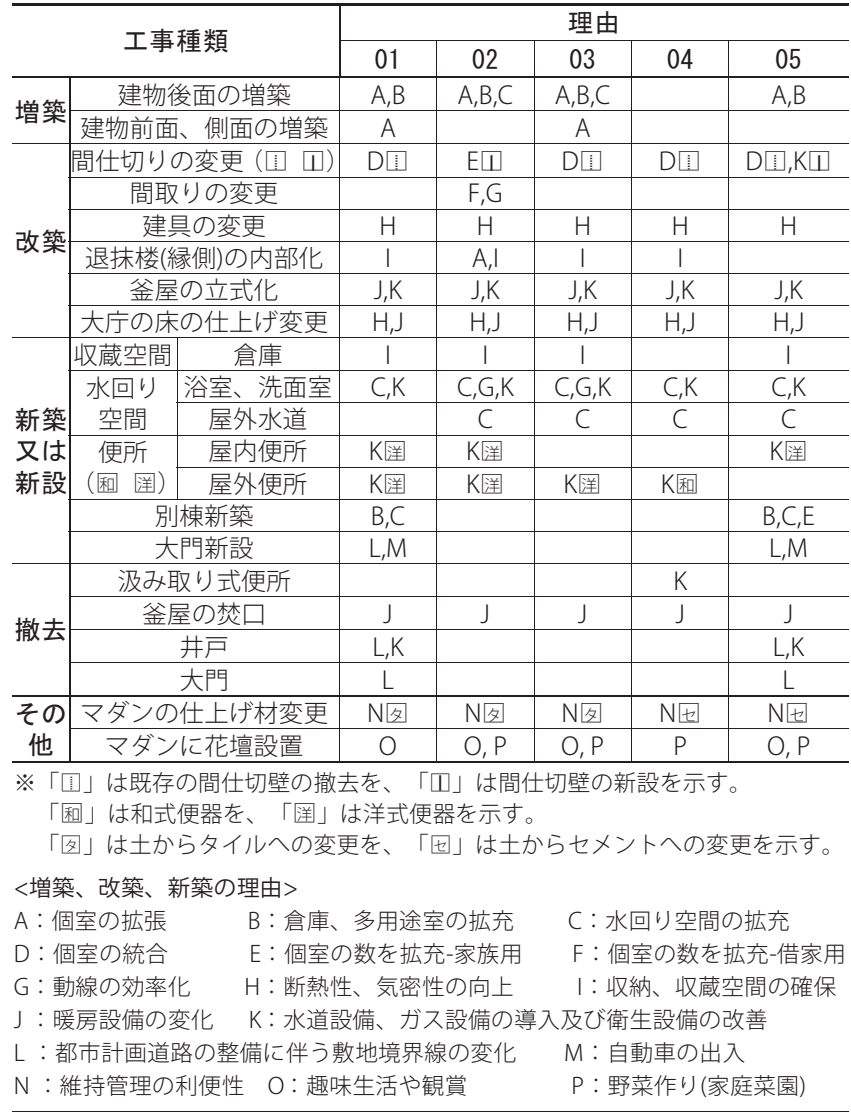

上はあるものの、釜屋から行き来しやすくするために壼を屋上に移 さずそのまま地面に置いている(別棟の屋上は図 3 の「rt」に対応)。

一方、別棟の屋上空間は、壼の置き場のみならず、穀物や洗濯物を 自然乾燥させる場所としても随時使われている。

\section{(3) 趣味生活及び休息空間}

この使われ方は、主に家で常住する高齢の世帯主による。事例 01 では草花が好きな世帯主の趣味生活のために園芸が行われており、 全て観賞用の草花や木である。マダンの中央には大きな松の盆栽が 二つあり、大門の左側や屋外トイレの前面にはランや小さい草花の 植木鉢がある。事例 02〜05 では、固定した花壇に観賞用の木を植え ている。さらに、事例 01〜04 では、別棟の屋上にも観賞用の植木鉢 を置いて園芸をしている(図2)。

観賞用の草花や木だけではく、食用の野菜を栽培するための家庭 菜園も作られている。事例 02 ・03 ではマダンの中央に、事例 04 ・ 05 では大門の近くの花壇に、食用野菜を植えて家庭菜園を作ってい る。事例 02 ・04 では、真ん中に食用野菜の植木鉢を置いて栽培して いる。その他に、事例 03 では、マダンの一角(息子寝室の前面)に鶏 小屋を置き、ほとんどの時間を家で過ごしている世帯主が趣味生活 として鵎を飼っている。

\section{(4) 駐車空間}

事例 01 ・05 では、園芸や家庭菜園を作りつつもマダンの中央は空 地の状態を維持し、駐車空間を確保している。4.3 で述べたように、 事例 01 ではマダンの中央に大きな盆栽の鉢があるが (図 2)、有事の 際にマダンを広く使えるように転がせる可動式に制作している。入 居当時は子供の遊び場や家庭の行事、家事作業をサポートするため に空地の状態を維持していたが、現在は駐車空間として利用するた
めにマダンの空地を確保している。

\section{3 小結}

チェは、屋内空間の断熱性や気密性を重視し建具の変更が行われ、 収納空間確保のために半屋外空間である縁側が内部化されており、 全体として使われ方が閉鎖的に変化している。

マダンは、住まい手の住要求に対応し、日常生活をサポートする 空間として使われてきている。一方、マダンの中央を空地に維持す る目的は、車の使用や家族ライフサイクルの変化に伴い事例 $01 ・ 05$ では主に駐車空間として、事例 02～04 では主に園芸及び家庭菜園な ど、退職後の世帯主の趣味生活の場として使われており、使われ方 が固定化していると考えられる。

\section{5.出入関係から見たチェとマダンのつながり方}

ここでは、第 4 章までの内容を踏まえ、チェとマダンにおける出 入関係を、増改築による入居時と現在の物理的な状態と、実際の使 われ方との対応関係にもとづいて検討する。図 3 では、入居時と現 在の空間組織を把握することにより、物理的な出入口の変化を明ら かにした。さらに、物理的には出入可能であるが、実際には使われ ていない出入口を把握し、チェとマダンの出入口の物理的状態と実 際の使われ方の対応関係を示した。

\section{1 出入口の消滅}

全体としてチェの各室からマダンへの出入口が減っている。事例 01 では内房(図 3 の「MR」、以下、MR)、事例 02 では部屋 (図 3 の「R」、 以下、R、図 2 の息子夫婦房に対応)、事例 03 では内房 (MR) と部屋 $(R$ 、 図 2 の息子寝室に対応)、事例 04 では内房(MR) と部屋 (R、図 2 の越 房に対応) からマダン $(\mathrm{M})$ か出入口がなくなっている。大庁 (図 3 の「L」、以下、L) は、チェの各室とマダンをつなぐ動線の接点とし て機能している。このことは、4.1 で述べたチェの使われ方の閉鎖 化と関連がある物理的変化だと考えられる。

釜屋 (図 3 の「K」、以下、K) とマダンの物理的な出入関係は入居後 から現在まで維持されており、さらに、実際に使われている。地面 にあった䇛の置き場を別棟の屋上 (図 3 の「rt」) に移つたため動線 が長くなったが、壼を使う生活習慣は維持されていることが分る (図 3) (関連内容は 4.2(2)にも述べている)。一方、5 軒の事例の中で唯 一釜屋の位置を変更した事例 02 においても、嗀を使うことによって 釜屋 $(\mathrm{K})$ とマダン $(\mathrm{M})$ の出入関係が存在する。

\section{2 チェの使われ方の閉鎖化}

前章までの検討内容によると、チェとマダンの出入口が物理的に 消滅している場合、二種類の変化の仕方がみられた。一つ目は、壁 を取り付けて開口部が全くない空間に改築することである。例えば、 入居時は半屋外空間として存在し、マダン (M) との物理的、生活的つ ながりを持っていた事例 04 の縁側 (図 3 の「L”」、以下、L”) は、現 在は壁に囲まれた収納空間となっており、マダン $(\mathrm{M})$ との物理的つな がりもなくなっている(図 2)。二つ目は、出入口はなくなったもの の、風通しや採光などの環境調整機能は維持するために空がある内 部空間に改築することである。このような物理的状態の変化および 生活における使われ方の変化は事例 02～05 の内房 (MR、図 2) 及び事 例 01 の息子夫婦房で行われており、大きい出入口をなくして空を付 け、環境調整機能を維持している(図 2)。

物理的な出入関係は存在するが、実際には使われていない現状か 

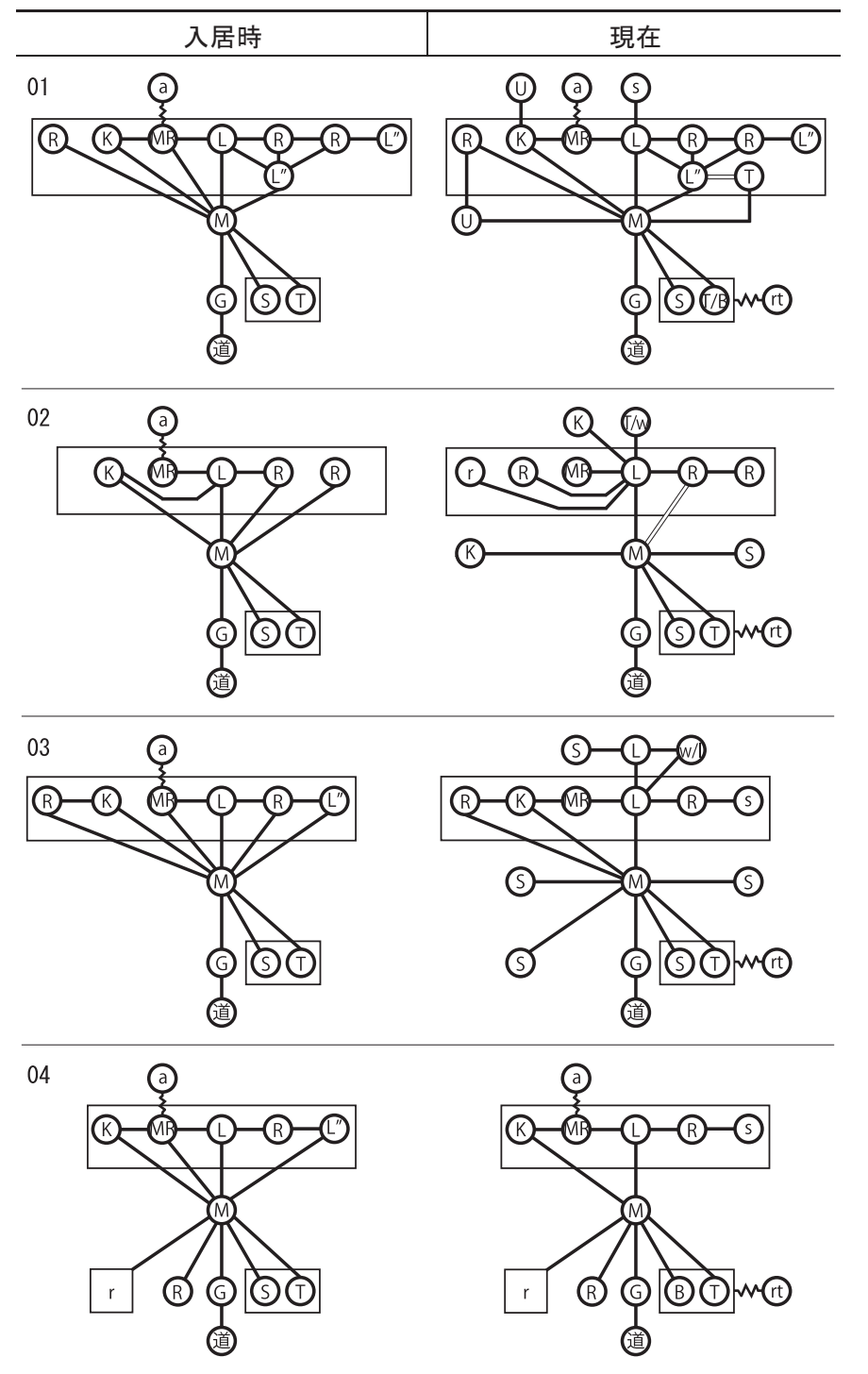

05
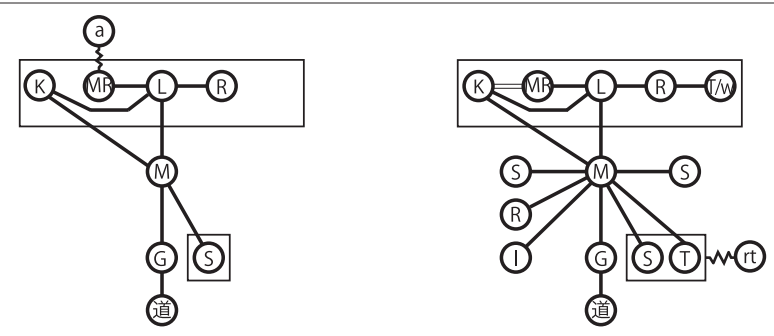

※この図では、建物後面にある屋外空間はとチェの出入関係については示さない。

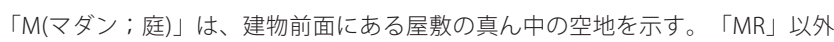
の部屋は、全て「R」と記す。02 事例の「L」は、住まい手による実際の呼び名は 居室である。02・04 事例の「r」は、間取りは保持されているものの、実際の使 われ方は物置となっている(以上について図 2 を参照)。

図内の英字は図 2 の英字に対応する。

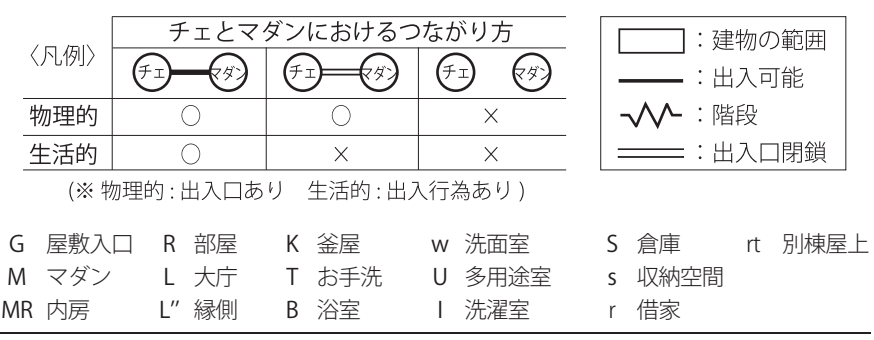

図 3 出入関係に見るチェとマダンのつながり方
らもチェの使われ方の閉鎖化が指摘できる。事例 01 の息子夫婦房の 場合、元々出入口があった部分に密を 2 か所作ったものの、家具の サイズが大きく種類も増えてきたため、実質的に採光や通風機能が 果たせる空は 1 か所のみである。事例 02 では、大庁 (L)の横の部屋 (図 3 の「R」、図 2 の孫房) とマダンとの出入口があり物理的にはつなが っているものの、空間を個室化し出入口の方に机をおいて生活して おり、実際には出入することができない。

以上から、対象事例では、入居当時よりチェの各室とマダンとの 出入口が減少し、屋内外空間の物理的接続そのものが少なくなって いることが分かる。また、物理的な出入関係は存在するが、実際に は使われていない現状から、チェの各室とマダンとの物理的、生活 的つながりが豊かな住み方よりは、限られた敷地の中で内部空間を 最大限確保寸ることを優先していると言える。それにより、チェの 使われ方が閉鎖化していることが分かる。

\section{6. 結論}

\section{（1）増改築による物理的状態の変化について}

対象事例では、空間の不足を補うために建物後面の増築が行われ ていること、半屋外空間である縁側が収納空間として内部化されて いることが明らかになった。その結果、チェとマダンにおける物理 的つながりが希薄化していることが分かった。こような現状から、 事例全体としてチェの各室をより閉鎖化する増改築が行われてきこ とが指摘できる。

また、水道の普及、燃料の発達に伴う衛生設備の改善、炊事と暖 房設備の改善のために水回り空間が増改築されていることが明らか になった。このことから、住設備に対する住まい手のニーズや、そ れらに起因した物理的変化が大きいことが分かった。さらに、断熱 性と気密性を重視し建具が木製枠からアルミサッシへと変更されて いることが分かった。

(2) チェとマダンの使われ方の変化について

チェは事例全体として使われ方が閉鎖的になっていることが分か った。屋内空間の断熱性や気密性を重視し建具の変更が行われ、収 納空間確保のために半屋外空間である縁側が内部化された。その結 果、季節による建具の開閉により住まい手自らが屋内外空間のつな がりを調整する住从方は失われつつあると考えられる。

マダンは、事例それぞれの住まい手の住要求に対応し、日常生活 をサポートする空間として使われ続けている。一方、マダンの中央 が空地に維持されている事例の場合、その目的は、車の使用や家族 ライフサイクルの変化に伴い事例ごとに異なっており、目的に応じ て使われ方が固定化していることが分かった。

(3) 出入関係からみたチェとマダンのつながり方について

全体としてチェの各室からマダンへの出入口が減っており、大庁 は、チェの各室とマダンをつなぐ動線の接点となっている。一方、 釜屋とマダンの物理的つながりは入居後から現在まで維持されてお り、壼の利用実態から釜屋とマダンには使われ方の点でもつながり が存在することが分かった。

チェとマダンの出入り口が物理的に消滅する場合、その変化の仕 方は二種類あった。一つは、壁を設置して開口が全くない空間とす ること、また一つは、出入り口は塞ぐが、風通しや採光等の環境調 整機能を維持するための空はある空間とすることである。チェとマ 
ダンの物理的な出入関係は存在するが、実際の使われ方の点では出 入がなく、出入口を閉鎖している現状も見られた。

以上のように、対象事例では、時代や社会の変化に伴い増改築が 行われ、チェの物理的状態と実際の使われ方が閉鎖化している。ま た、マダンの使われ方における固定化が進んでいったと考えられる。

\section{参考文献}

1) Kim Haeri, Kim Taiyoung : A Research on the Spatial Change of the Main Room and Kitchen of Traditional Utbangkkeokeum House in Cheongju City, Journal of the Korean Housing Association, vol.20, no.6, pp.19-29, 2009.12

2) 金海梨, 高田光雄 : 都市韓屋におけるマダン(庭)の変容に関する調査研究, 日本建築学会住宅系第 7 回研究報告会論文集, pp.123-128, 2012.11

3) 金海梨, 高田光雄 : 韓屋におけるチェとマダンのつながりに対応した住生 活の特徴に関する一考察, 日本建築学会計画系論文集, Vol.80, No.718, pp.2763-2770, 2015.12

4) ハウジング・スタディ・グループ, 三沢博昭 : 韓国現代住居学一マダンと オンドルの住様式, 建築知識, 1990

5) Lee Youngho, Park Soobin : Study of the Meaning and Use of Madang through the Evaluation of the Detached House Residents in Busan, Journal of the Architectural Institude of Korea, vol.25, no.8, pp.153-162, 2009.8

6) 藤井英二郎: 日本と韓国における庭園を中心とした緑地の比較文化的研究、 文部省科学研究費国際学術調査研究成果報告書, pp.56-68, 1990

7) 清州大学大学院建築工学科 : 청주 구도심 성안동·중앙동 건축물 통계 자료(清州市旧市街地における建築物統計資料), 2007.8

8) Song Inho : A Study on the Types of Urban Traditional Housing in Seoul from 1930 to 1960, ソウル大学博士学位論文, 1990

9) Ha Jaemyung 5 : A Study on the Plan Types of Urban Traditional Housing, Journal of the Architectural Institute of Korea, vol.12, no.5, pp.75-83, 1996.5

10) Jeon Bonghee 他共著:韓屋と韓国住宅の歴史, Dongnyok, 2012

11) Yi Hoon, Kim Taiyoung : A Study on the Traditional Characteristics of Architectural Elements in Korean Modern House of Urban Areas, Journal of the Architectural Institute of Korea, vol.11, no.4, pp.3-16, 1995.4

12) 国土海洋部：韓屋建築振興のための技術基盤構築研究, 2007.8

13) Yoon Jinah : Spatial composition of the Urban Hanok in Seoul in the Great Han Empire Period, ソウル大学修士学位論文, 2007

注

注 1)一般的に「伝統韓屋」とは高麗時代から李朝時代 (918-1910)の貴族の住 んだ住宅を指す。伝統韓屋では、複数のチェ(住棟、以下、チェと記す。) と複数のマダン(庭)が一体となって一つの住宅が形成された (伝統韓屋に おけるマダンの特徴については参考文献 3 を参照)。伝統韓屋のチェでは、 夏を快適に過ごすためのマル (抹楼 ; 板張り空間) と冬を快適に過ごすため のオンドル (温突 ; 床暖房をつける部屋)が併置される。一つの住棟に夏の 空間と冬の空間が共存することは韓屋独特の作り方で、住まい手は建具を 開閉することや床暖房をつけることによって季節に対応する。

注 2) 近年の新韓屋開発は、2011 年、大統領令による国家韓屋センター設立以 降、政策推進のための研究体制を本格化し、急速な展開を見せている。そ の前身になった国レベルでの動きは2 007 年からで、主に韓屋における冷暖 房設備の改善や構築技術の産業化などを目指した研究開発が行われてきた。 関連する内容は参考文献 12 に記されている。

注 3 ) 参考文献 3 による。

注 4) 都市韓屋は、文化財として原型保存の価值が最優先される伝統韓屋とは
異なって現在の住まい手の住要求に応じて自由に改変することができる。 そのため、現存する都市韓屋における空間の物理的状況や使われ方は建設 当時の意図通りに残されているとは言えない。より厳密に都市韓屋におけ る空間の相互関係やそれに対応した住み方を検討するためには、現時点で の空間の物理的状況や使われ方に着目する必要がある。

注 5) 筆者らによる研究 (参考文献 1 2 ) を含めて、全国に散在している都市韓 屋の実態を扱った研究が多数行われた。中でも、都市韓屋密集地域である ソウルの北村を対象とした事例研究が多い。日本における関連文献として は参考文献 4 が代表的である。

注 6) 参考文献 5〜6 などによる。

注 7) 都市韓屋は狭い敷地を有効に使うために曲家となっている (参考文献

13)。曲家は L 字型を基本とし、コ字型や口字型等がある。

注 8）「京城地方型」ともいわれる。開花期の知識層を中心に朝鮮半島の住宅 についての調査研究が行われたが、1920 年代に入ると建築教育を受けた専 門家による住宅改良論が主張された (参考文献 11)。その際に中部地方型民 家や京城地方型民家は、間取りや曲がり方、構法のディテールが類似な住 宅型として扱われた。本稿ではそれらを「中部地方の L 字型韓屋」とする。

注 9) 清州市旧市街地に現存寸る都市韓屋で、住宅として使い続けられている 39 軒のうち、中部地方の L 字型都市韓屋は 20 軒であることを確認した (参 考文献 7)。その上で、建物や内部家具の実測、内外部空間の写真撮影、住 まい手に対するインタビューの許可が得られた 5 軒を本研究の対象とした。 本調査は 2007 年の 7 月と 2011 年の 9 月に行った。このような調査は、1994 年から持続的に清州市旧市街地の保全再生に係ってきた清州大学建築学科 近現代建築史研究室と地域住民との信頼関係の構築により可能となった。

注 10) 本稿で使う「都市韓屋」という用語は、学術用語として定められず、 「都市型韓屋」、「改良韓屋」とも言われる。Song Inho(参考文献 8) は、 「1930 年代から 1960 年代にソウルの住居地に集団的に分布する都市型住 宅」を「都市型韓屋」と定義している。Ha Jaemyung ら (参考文献 9) は、「1930 年前後から 1960 年頃までに都心部およびその周辺地域に建設された中小 規模の韓屋が “改良韓屋 ‘と呼ばれている」と説明する。また、改良韓屋 の特徴として「伝統韓屋が改良され、新しい機能と生活様式の変化によっ て建設されたもの」と述べている。本稿では、1930 年代から1960 年代に かけて都市型住宅として建てられた韓屋のことを「都市韓屋」とする。

注 11) 近代的建築材料として、ガラス、トタンや銅板などの鉄物、レンガな どがあげられる(参考文献 10 の pp. 151-158)。

注 12) 同じ L 字型でも、内房を基準に曲がる家や、釜屋を基準に曲がる家が ある。主にソウル・京畿・忠清などに分布する中部地方の L 字型韓屋は、 内房を基準に曲がる間取りとなっている。

注 13)この住宅型においても、伝統韓屋と同じくチェとマダンが一体化した 空間構成の特徵は引き継がれている。

注 14) 内房は、上の房(ウッバン ; 内房で奥の方に ある部分) と下の房(アレッバン; 内房で釜屋に 接している部分) と呼ばれる二つの部屋から成 る。例として図 2(右)を用いて内房の詳細を図 のように示す。

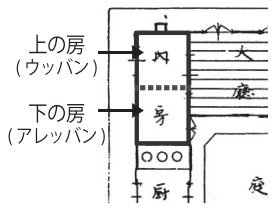

注 15) 韓国では 1920 年代に入ってから伝来住宅の衛生設備及び釜屋の改良論、 立式生活論、食寝分離論などのような住生活改善運動により、いわば「文 化住宅」という住宅型が出現し、官僚や商人階層を中心に欧米式近代住宅 として沢山建てられた。しかし、当時主唱されていた住生活改善論は、一 般市民階層の住んでいた都市韓屋では暖房と衛生設備の不備で実践するこ とができなかった(参考文献 11 の p. 4)。

注 16) 伝統韓屋の空間構成の特徴については参考文献 3 に説明している。

注 17) 環境調整空間とは、『「木の文化を大切にするまち・京都」市民会議「平 成の京町家」検討プロジェクトチーム検討報告書』（京都市、2010）にお いて、縁側や玄関土間のように、内部空間と外部空間を関係付け、建具の 開け閉めなどによって関係が調整できる空間として定義され、その後の環 境配慮型住宅計画で使われてきた概念である。 


\title{
THE RELATIONSHIP BETWEEN CHAE AND MADANG CORRESPONDING TO THE EXTENSION AND ALTERATION OF URBAN HANOK
}

\author{
Haeri KIM*, Mitsuo TAKADA** and Taiyoung KIM ${ }^{* * *}$ \\ * Grad. Stud., Graduate School of Eng., Kyoto Univ., M.Eng. \\ ** Prof., Graduate School of Engineering, Kyoto Univ., Dr.Eng. \\ *** Prof., Dept. of Architecture, Cheongju University, Dr.Eng.
}

"Urban Hanok" were mainly built between 1930's to 1960's in an urbanized area. It is consist of "Chae" and "Madang" which belong to the residential buildings. Combining of them makes up a living space. The Chae has two distinctive features. One is "Maru(a wooden floor)" and the other is "Ondol(underfloor heating system)". The former is good for bearing the hot weather in summers and the latter is to survive in the cold winters. The unit of Chae and Madang functioned as a versatile living space or an environmental conditioning space. L-shaped urban Hanok building is consist of two parts. One zone is the main building and the other is wing building. Anbang is connected the main building and the wing building. Buok(a kitchen with a fuel hole) is located next to the Anbang toward the wing building, while Daechung(the main wooden floored room) is next to the Anbang toward the main building.

The purpose of this study is to identify the characteristics in relationship between Chae and Madang corresponding to the extension and alteration of L-shaped urban Hanok, which is a standard urban Hanok shape in central Korea. Based on the actual condition of the extension and alteration, we examined the spatial modifications in Chae and Madang and evaluated the characteristics of life style corresponding to the connection between Chae and Madang.

The results are follows:

(1) About the changes in the usage of Chae and Madang due to extension and alteration: (1)The usage of Chae: The backside of a building was extended to increase a room space or acquire a storage space. In this process, the gate part, which connected rooms in a Chae and front garden, was altered. When a gate was removed and replaced with a wall, the backside of a building and exterior space is disconnected. When a gate was replaced with a window, the space only allowed minimum lighting and ventilation. The passage to Madang is maintained, keeping traditional path of circulation intact. (2)The usage of Madang: Life behavior at the Madang changed corresponding to the demands of residents. For example, retired residents enjoyed gardening. However, Madang was maintained as an empty space for a parking spot, which was a different usage compared to when they just moved in. Madang had been flexibly used as a space to support the daily life of residents. Reason of emptying the center of Madang had changed corresponding to the variations in life pattern.

(2) About the changes in the connection between Chae and Madang: As characteristics of connection between Chae and Madang and space usages corresponding to the extension and alteration, it could be pointed out that rooms of Chae became more exclusive than when they moved in. For example, gates from rooms of Chae to Madang were removed and only the gate connecting Daechung and Madang was maintained. Toenmaru, which was a half inside and half outside space, used to connect Chae and Madang, but it turned into a pathway and storage space. Therefore, it changed the traditional lifestyle, which allowed residents to change the connection between interior and exterior by opening and closing windows and doors corresponding to seasons. 